Article

\title{
A Methodological Approach for the Assessment of Potentially Buildable Land for Tax Purposes: The Italian Case Study
}

\author{
Fabrizio Battisti ${ }^{1, *}$, Orazio Campo ${ }^{1}$ and Fabiana Forte ${ }^{2}$ \\ 1 Department of Planning Design Technology of Architecture, Sapienza University of Rome, Via Flaminia 72, \\ 00196 Rome, Italy; orazio.campo@uniroma1.it \\ 2 Department of Architecture and Industrial Design, University of Campania "Luigi Vanvitelli", Via San \\ Lorenzo ad Septimum, 81031 Aversa, Italy; fabiana.forte@unicampania.it \\ * Correspondence: fabrizio.battisti@uniroma1.it; Tel.: +39-338-1079177
}

Received: 6 November 2019; Accepted: 23 December 2019; Published: 1 January 2020

\begin{abstract}
According to Italian legislation for a particular type of real property-lands/areas subject to buildability, but not yet currently buildable-there is a problem related to their "qualification", or whether or not they must be considered buildable for the purposes of their recurrent taxation. These potentially buildable (POBU) areas, that were previously zoned as "agricultural", have been rezoned as "general urban planning instruments/regulations" (the General Urban Development Plans or variances, which regulate land governance), whose approval path has yet to be concluded. Their value - the taxable base underpinning their taxation-clearly depends on their qualification (whether or not they are considered buildable). This has produced, in recent years, several disputes between owners and local governments; the law did not give univocal solutions: Today (2019), there is a conflict of case law in relation to considering these areas as being building areas, as it is not clear what estimating procedures should be used. This article is thus based on the assumption that responding to the problems connected with taxing POBU areas must be considered separately from (overcoming, in this way, conflicting case law) the "virtual" qualification of agricultural or buildable area, but must instead, and more simply, be considered as the actual condition it is found in (likelihood of having building potential in the future), and therefore its limitations (present at the time of taxation) and the time necessary for the building to actually be built and not just "potential". The approach proposed in this article thus offers a solution to the problem that has been raised, by modifying the current de jure approach (defining the moment when the building right is manifested) towards an assessment/appraisal approach (defining the value of the potentially buildable (POBU) area, in relation to its actual conditions). To implement this approach, a methodology-proposing an upgrade of the traditional analytic procedure for the assessment of transformation value has been structured in a way such that consideration may be made of the components characterizing the potentially buildable areas by means of appropriate assessment parameters that go towards forming these areas' value: These are the market value discount rate of the POBU area in relation to the uncertainty and risk of reaching effective and concrete buildability, and the estimated time needed to complete the procedural path for making the area actually buildable.
\end{abstract}

Keywords: land taxation; appraisal; buildable land; real estate; transformation value; market value

\section{Introduction and Aims}

In the Organization for Economic Co-operation and Development's (OECD) classification, taxes on financial and real estate assets include taxes on real property, on net wealth, on gratuitous transfers of ownership (succession and donations), and on financial and capital transfers. With reference to 
taxation on real property, an important distinction is that between "recurrent" taxes, which typically take on the form of yearly payments owed by the owner, in an amount linked to some measure of the property's periodically reassessed or indexed value, and "non-recurrent" taxes on transactions, which are generally paid on the occasion of the sale or transfer of the property.

This article examines recurrent taxation for a particular type of real property: lands/areas subject to buildability, but not yet currently buildable. These areas will be referred to in this article as potentially buildable (POBU): all those areas that have been rezoned from "agricultural" to a "general urban planning instruments/regulations" (the General Urban Development Plans or variances, which regulate land governance), whose approval path has yet to be concluded.

For real property types, there is a problem related to their "qualification", or whether or not they must be considered buildable for the purposes of their recurrent taxation. Their value-the taxable base underpinning their taxation-clearly depends on their qualification (whether or not they are considered buildable).

On a European level, European Union(EU) law has left to the jurisdiction of the member states the choice of determining the moment when the areas subject to taxation acquire, for tax purposes, the trait of buildability; however, in several other member states, the issue of qualifying areas of this type is unresolved (2019) to this day.

This problem, relating, then, to qualification for POBU areas, is a consequence of the division—commonly encountered in Europe-of legislative and administrative competences relating to spatial planning between the state and local authorities [1].

Taking the Italian case as a particular reference, buildability is attributed to the areas by municipal-level general urban planning instruments, or sometimes also by operative instruments more circumscribed in scope, that make variations to the municipal instruments in force [2,3]. The approval of a general urban planning instrument (or its variances) consists of a number of phases, of which the essential ones are adoption by the municipality and subsequent approval by the region, having obtained all the opinions and/or clearances from the various sectoral authorities that have responsibility in urban planning proceedings [4]; it is then possible for building to be subordinated to the prior approval of an implementation instrument (detailed plan, development plan, public housing construction plan, etc.). From the urban planning standpoint, also by virtue of what are termed "safeguard provisions"1, a plot of land may be referred to as "buildable" only after the general urban planning instrument has gone into effect and, if necessary, also after the general urban implementation planning instrument has gone into effect; in fact, only after that time can the building permit actually be obtained; this articulated process may have a considerable duration, even of several years. From the standpoint of taxation, on the other hand, for the purposes of yearly taxation (single municipal tax, known as "Imposta Municipale Unica" or IMU), in accordance with the orientation prevailing in Italy, even the mere adoption of the general urban planning instrument qualifies the area-erroneously-as "buildable," and is therefore assessed as such for the purposes of its recurrent taxation.

This means that over a POBU area, the exercise of the building right is not permitted, while recurrent taxation is, however, commensurate with that right, even if it cannot be exercised. Thus, for some time, an owner can find themselves subject to taxation for a right that, de facto, cannot be exercised.

However, this issue has for some time been "countered" in Italian case law; it bears pointing out that Europe, too, sees litigation on the subject, as well as conflicting decisions aimed at determining the moment when the areas subject to taxation acquire the characteristic of buildability.

1 Safeguard provisions are, at the present time (2019), present in the Italian legal system by virtue of art. 12 , paragraph 3 of Presidential Decree no. 380/2001. They require, in the event of adoption of urban planning provisions varying those previously in force, that the more restrictive of the two be taken into consideration, up to a maximum of three or five years (depending on the start of the approval phase) after the adoption of the general urban planning instrument in variance. 
In Italy, at the present time (2019), in a situation of scant clarity, the main orientation continues to be that of considering the value of POBU areas for the purposes of their recurrent taxation on the basis of the building right, even if attributed by a general urban planning instrument that has only been adopted, and therefore cannot be exercised. Among other things, this approach fails to consider that POBU areas, if pledged as collateral for loans, are considered as a function of their agricultural value. The European Central Bank (ECB), in fact, in its Asset Quality Review reviewing the assets in the financial statements of the 130 leading European banks in order to verify their health, has established methods and criteria to appraise collateral, which is to say, of the assets used to guarantee the loans granted by these banks. As to the buildable areas, the ECB has established that they can be considered as such, and therefore their estimated value as a function of their building potential, only if the authorization process has been completed and the building permits have been issued; in all other cases, the assessment principle to be considered is agricultural value $[5,6]$.

The often onerous taxation to which POBU areas are subject, along with the uncertainties and the long bureaucratic process for completing the process for approving the various instruments necessary to provide these areas with building rights, along with their "sterility" for extending credit, are the cause of numerous negative effects, such as: (i) Frequent failure to pay IMU by a significant number of taxpayers owning POBU areas; (ii) cases of tax evasion and avoidance; (iii) gradual weakening of the vitality of the real estate market in POBU areas, which is translated into a reduction (current or future) of real estate development initiatives [7].

Fair taxation of POBU areas may represent an initial and significant step to counter the aforementioned negative effects [8,9]; towards this end, the first step to take is the exact determination of their market value. This article, which is centered mainly on appraisal/assessment-related studies and research, is thus based on the assumption that responding to the problems connected with taxing POBU areas must be considered apart from (overcoming, in this way, conflicting case law) the "virtual" qualification of agricultural or buildable area, but must instead, and more simply, be considered as the actual condition it is found in (likelihood of having building potential in the future), and therefore its limitations (present at the time of taxation) and the time necessary for the building right to be actually exercised and not just "potential" [10]. The approach proposed in this article thus offers a solution to the problem that has been raised, by modifying the current de jure approach (defining the moment when the building right is manifested) towards an assessment/appraisal approach (defining the del value of the POBU area, in relation to its actual conditions).

To implement this approach, the analytical/indirect estimate method of transformation value (hereinafter, simply "transformation value") may be used; however, this methodology must be operatively articulated in such a way that consideration may be made of the components characterizing the POBU areas by means of appropriate assessment parameters that go towards forming these areas' value: These are the market value discount rate of the POBU area in relation to the uncertainty and risk of reaching effective and concrete buildability, and the estimated time needed to complete the procedural path for making the area actually buildable.

In light of this, then, this article has the objective of:

- Establishing the modes of implementation of the transformation value for the estimate of a POBU area, specifically considering the components characterizing these types of area.

- Allowing the components characterizing the POBU areas to be identified, thus making the proposed approach operatively practicable, by structuring a method that, through its application, makes it possible to estimate the components characterizing the POBU areas (discount rate and times) that take on essential importance in the implementation of the transformation value in accordance with the proposed approach.

The results expected by this article, therefore, consist of the proposed approach's operative applicability, that makes it possible to appraise a POBU area regardless of its "legal" qualification as buildable or non-buildable area, but in consideration of its actual condition; the result of the estimate represents the market value to be made the taxable base for recurrent taxation. 
Below, Section 2 carries out a context analysis relating to the main issues connected with the taxing of POBU areas and attributing building potential, with general reference to the European situation and specifically to the Italian situation. Section 3 analyzes materials and methods available to estimate POBU areas, and specifically identifies the procedures for implementing the analytic/indirect method of transformation value for the appraisal of a POBU area. Section 4 structures a methodology that will allow us to estimate the parameters characterizing POBU areas, thus making the analytic/indirect method of transformation value implementable. In Section 5, the structured methodology is tested for an operative study case, in order to identify the parameters characterizing POBU areas: discount rate and conclusion times of the processes of attributing building potential. Section 6 draws the conclusions of this article.

\section{Context Analysis}

\subsection{The European Context}

An analysis of the recurrent taxation of properties in European countries [11-15] has shown the existence of two questions relating to real estate taxation; both involve assessment problems: (1) defining the applicable rate in the recurrent taxation of properties; (2) estimating a value that must be considered as a taxable base (to which to apply the aforementioned tax rates).

The questions relating to the first question, on defining tax rates, are under the responsibility of legislative and executive/administrative power [16-18]: the decisions regarding these issues are strictly political in nature, and are generally taken in relation to the balancing of public accounts [19-22].

Issues relating to the second question, as to attributing a taxable base value, have a strictly technical characterization and can be dealt with via a proper appraisal of the immovable asset being assessed, in consideration of its features [23].

Focusing on the question relating to the assessment of POBU areas for tax purposes, it bears summarizing how the building rights from which the tax problems highlighted in the previous paragraph, and that motivated this article, are attributed in Europe.

Analysis of the constitutions of a significant sample of European Union member states (Italy, France, Portugal, Austria, Germany, The Netherlands, Spain, Greece, and the United Kingdom, the latter in the phase of ending its membership in the European Union) has cast light on how none of them have outlined a full-blown spatial planning system, the configuration of which is therefore usually devolved upon ordinary lawmaking. The European Commission, in The EU compendium of spatial planning systems and policies [24], categorized the Member States' various approaches in the matter of urban planning and consequent attribution of building rights:

a. The regional economic planning approach, in which spatial issues are compared with economic ones and planning takes account of and integrates both aspects. This system is typical of France and Portugal.

b. The comprehensive integrated approach, marked by a hierarchy of plans (top-down) and aiming more towards spatial coordination than towards economic development. This system is typical of Austria, Germany, and The Netherlands.

c. Land-use management, aimed mainly at controlling and regulating land use, with regard to a sustainability parameter. This approach is typical of the United Kingdom.

d. Urbanism, circumscribed to the urban and building dimension. This approach is widespread in the Mediterranean area, and is typical of such countries as Italy, Spain, and Greece.

Although European planning follows several different approaches, the procedural paths of urban the planning processes by which the areas subject to planning are zoned and, where necessary, attributed building rights, is, in general, the same in a European setting: Responsibilities relating to spatial (and economic and social) planning are divided between the state and local authorities. The decision as to an area's buildability, on the other hand, is generally the responsibility of local 
authorities/bodies; the formal attribution of building rights is vested with bodies/authorities at the supra-local level [1,25-27].

With this approach, the process of attributing building rights to an area subject to planning does not depend on instantaneous administrative action yielding juridical effects from the moment it is taken, but is the outcome of an administrative process extended over time.

This situation raises questions common to several member states relating to the taxation of real property/areas, during this administrative process, which is then the subject of this article.

On the European level, EU law has left to the jurisdiction of the member states the choice of determining the moment when the areas subject to taxation acquire the characteristic of buildability and, consequently, upon which the taxable base of value to underpin both recurrent and non-recurrent taxation depends. This approach is not made apparent by specific EU directives, but by certain decisions of the Court of Justice of the European Union (CJEU). Generally speaking, the CJEU's prevailing orientation is to legitimate member states in defining the notion of buildable land, and what characteristics a plot of land must have in order to be considered buildable (as may be gleaned from the decisions in cases C-468/93, C-461/08, C-326/12, C-461/08, C-326/11, C-180/10, and C-181/10); this problem is thus devolved upon the several member states.

\subsection{The Italian Context}

Throughout the twentieth century and to this day (2019), various tax instruments for incomes have been launched, the outcome of urban planning choices, first through extraordinary taxes (improvement contribution, introduced in 1923; followed by INVIM, the tax on the increased value of real property) and then through ordinary taxation [10]: It is, in fact, the 1990s that saw the introduction of the municipal real estate tax (Imposta Comunale sugli Immobili-ICI), representing one of the most significant sources of income for municipal budgets; this later became the Single Municipal Tax (Imposta Municipale Unica-IMU) in 2011, with which lawmakers enshrined reliance on ordinary taxes on the asset value of real property, alongside the traditional income-based taxation of legal and natural persons.

In Italy, in agreement with what has been highlighted in the EU environment in the area of recurrent real estate taxation, the IMU rate for taxation is established by the revenue agency (Agenzia delle Entrate) and amounts to a percentage of the real property's market value, which the municipalities are responsible for assessing.

It was argued earlier that in Italy, for the POBU areas considered as such based only on the General Urban Development Plan (Piano Regolatore Generale-GUDP) or, more frequently, on the General Variance (Variante Generale-GV) ${ }^{2}$, adopted by the municipal administration but never approved, building rights cannot be exercised ${ }^{3}$; they can be exercised only after approval both of the PRG/VG, issued by the regional or provincial administration, and of an urban implementation plan, and after having obtained the qualification documents (building permits) ${ }^{4}$.

The nearly unanimous trend of municipal administrations in Italy, with regard to the taxation of POBU areas, has always been that of considering, as a taxable base for applying the tax rates, the building potential value, even if it cannot be exercised immediately. As already discussed, this has created several disputes in recent years, for which case law has not provided a univocal solution. Two contradictory orientations have emerged over time [4]:

2 GUDP/GV means any modification/revision of a "general" and not "specific" nature, of the GP in force. Since nearly all the municipalities have approved GUDP and therefore in force, the overall planning practiced by the CC in Italy, as of 2015, only applies to GV; under a formal and substantive standpoint, GUDP and GV have similar and coincident tools.

3 As a rule and unless it is an extension of zone B in accordance with Ministerial Decree no. 1444/68.

4 Building Permit by the relevant technical departments of the CC or alternatively Activity Start Report (DIA) where permitted (where the implementation urban plan provides for building types is still thorough in the aspects as well as urban planning, even building). 
i. A first (and prevailing) orientation that holds that for the purposes of IMU, simply inserting the plot of land into the adopted GUDP/GV with zoning that admits buildability is sufficient for it to be taxed as such. This orientation is based on the assumption that inserting the plot of land into the GUDP/GV as a developable area results in a clear and inevitable increase in its value, and therefore the IMU tax must be set in relation to this value, while its actual unbuildability appears wholly without influence (article 5, Legislative Decree no. 504/1992; Cassazione (supreme court of cassation), decision no. 16751/2004; Cassazione, decision no. 19750/2004; article 11 quaterdecies, paragraph 16, Legislative Decree no. 203/200, converted by Law no. 248/2005, art. 36, paragraph 2, Legislative Decree no. 223/2006, converted by law no. 248/2006; Cassazione, united sections, decision no. 25506/2006; Constitutional Court, order no. 266/2008);

ii. A second orientation that holds as insufficient the circumstance of entering the plot of land in the GUDP/GV in order to tax it as developable area, if in fact this land remains unbuildable. In this case, the plot of land must be considered, and therefore taxed for the purposes of IMU, as agricultural land (Cassazione, decision no. 21644/2004; Cassazione, decision no. 17035/2013).

To provide some data for comprehending this problem's spread, an investigation was carried out on the size of the POBU areas in the Lazio Region. The investigation was conducted thanks to the availability of documents relating to the state of planning for each of the region's municipalities; these documents are partially available online [28]; they were in part (updates for the 2012-2019 period) viewed at the Regional Directorate for housing policies and territorial, landscape, and urban planning of the Lazio Region.

In terms of area covered, with its $17,232 \mathrm{~km}^{2}$ the Lazio Region represents $5.7 \%$ of Italy; with 5987 million inhabitants, it accounts for $9.9 \%$ of the Italian population.

Consultation of the available data on the state of planning showed that 51 municipalities out of 378 for the entire Lazio Region have GUDPs/GVs in progress, adopted but not yet approved. At the Lazio Region's Urban Planning Directorate, the GUDP/VG instruments in progress in the 51 mentioned municipalities were consulted; taken together, the POBU areas amount to about $580 \mathrm{~km}^{2}$ : thus representing $3.4 \%$ of the regional territory.

Taking the Lazio Region's data as a sample indicative of a situation that may be found throughout national territory, as initial approximation POBU areas may be estimated in Italy within a range (as a round figure) between 9000 and $12,000 \mathrm{~km}^{2}$ (between $3 \%$ and $4 \%$ of the national territory).

Taking into account the previous data, the amount of tax revenue originated from POBU areas can be assessed, approximately, in $1.2 \%-1.5 \%$, of the total amount of municipal revenue [29]. However, it should be considered that much of this revenue is not paid and it is the object of dispute in fiscal courts.

The proposed method just "theoretically" sets up a reduction in municipal tax revenue; actually the fair appraisal of POBU areas, possibly also jointly performed by the municipality and owners in accordance with article 12 of Legislative Decree no. 218/1997, could reduce the phenomena of non-payment of taxes and the fiscal disputes and it also could increase, in fact, tax revenues without intervening on the tax rates.

\section{Materials and Methods for Appraising a POBU Area}

\subsection{Methodological Approach}

The questions related to recurrent real estate taxation are analogous to those of any immovable asset: attributing a rate and appraising the value to be made the taxable base. In the case of areas/land, in accordance with what was analyzed earlier, the practice provides for preliminary qualification of the area to be made the base for taxation, since its value depends on its qualification (whether or not buildable). 
This approach, widespread in the EU and in Italy in particular, becomes "rigid" when referring to POBU areas, since they are neither agricultural nor buildable, but areas with a potential to accommodate a building right.

The methodological approach proposed in this article, aimed at assessing the market value (taxable income for applying the tax rate), calls for appraising the POBU area "as is"; the estimated value can represent the congruous, fair taxable base in the direct (yearly) taxation of this kind of property.

In accordance with international assessment standards [30-32], a property's market value (including the buildable areas) must be estimated considering its highest and best use (hereafter, HBU).

The HBU considers a real estate resource's most profitable use, taking note of the fact that potential purchasers are willing to pay a price that reflects their expectations as to the most fruitful use of the resource, chosen in the context of the uses that are possible and permitted by regulations. The HBU thus reflects a current (market) value of a property, with a view to its best use-current or attainable upon adequate transformation. To implement the assessment of a property's HBU, it is therefore necessary to estimate its market value proper (relating to the direct use of the asset), the different transformation values (as many as there are possible logical transformations), and any subrogation values. The highest of these values corresponds to the HBU. The most profitable use may also be the current one if the market value (direct utility) is greater than the alternative uses (indirect utility) [33].

With reference to the above, the specific objective of this article is to provide elements to determine the market value of a POBU area through an appraisal methodology recognized on a European level—in the specific case, as to the buildable areas, in accordance with the most widespread current scientific literature, in order to implement the HBU, it is necessary to estimate the transformation value, using the transformation value method [33].

Considering that EU planning practice ordinarily assigns to an area susceptible to being urbanized a univocal intended use and a building potential index, it follows that the possibility of transformation, at least in the planning phase itself, is only one, and that its market value thus coincides with the transformation value with regard to the only admitted transformation option.

In implementing the transformation value, given the particular nature of the POBU areas, two variables that come into play as a discount parameter bear consideration: (i) The "juridical/administrative" characteristics that influence a POBU area's convertibility; (ii) the time needed to conclude the planning processes in order to modify the planned use of the areas.

To make the implementation of the transformation value practicable, the two variables must be transformed into parameters usable in the context of assessment: variable 1 is translated into a discount rate, the sum of various coefficients correlated with the different "juridical/administrative" characteristics; variable 2 is translated into the discount rate's exponent [33,34].

In order to obtain discount coefficients in relation to the "juridical/administrative" characteristics of POBU areas, a methodology has been structured that, through the use of inverse power functions, elaborates the price differentials found in the market of areas with different juridical/administrative characteristics, and yields discount differentials specific for the individual characteristics.

To be able to define the "time" parameter, a "historical/assessment" approach is proposed through which, having analyzed a significant number of administrative proceedings aimed at attributing building potential to an area, the duration of the various steps in which this process is articulated can be extrapolated, thus being able to estimate the times for implementing the various examined cases, and to draw relevant hypotheses by analogy.

The approach proposed from a methodological standpoint can find a use in an international setting: The assessment of the property to be subject to "recurrent" taxation involves all the member states; in this way, the appraisal of the value of a POBU area is rid of juridical issues and becomes a technical one that can be resolved through the use of instruments that the appraisal regulation makes available, as operatively articulated and proposed in this article.

However, moving forward the procedure will be "calibrated" on the basis of the Italian case; the proposal intends to align itself with the content of the decision of Supreme Court of Cassation, United 
Sections no. 25506/2006, which finds that the start of a process that will provide an area with building rights does not correspond to immediate building rights, and therefore, for tax purposes, the greater or lesser importance and the potential of its building rights must be considered.

\subsection{Appraisal Tool: The Transformation Value Method}

Each buildable area presents specific characteristics; in general, "physical" characteristics of the area may be identified, connected with the position (elevation, sunlight, orientation, etc.), infrastructures and accessibility, the land's geological, hydrogeological, and mechanical properties, environmental characteristics, and so on, as well as the "juridical/administrative" characteristics of the buildable area, connected with specific limitations and constraints that act upon that area, thereby impacting - at times even significantly, the limitation of the building rights.

In this sense, as "physical" characteristics that connote an area that is or about to become buildable, they impact its value (impacting the market value of the assets that can be realized, and their production costs); likewise, the "juridical" characteristics and the "temporal" repercussions impact the value of an area that is or about to become buildable.

Although in recent years various real estate assessment procedures have been proposed [35-37], in the current case the most appropriate procedure is identified in the traditional so-called transformation value method (TVM), to estimate a real asset's transformation value, which corresponds to the current (market) value of said asset in relation to the tangible and legally admissible possibilities of being able to transform it [38]. According to the most widespread scientific literature in the area of EU and also Italian appraisal, as discussed in paragraph 2.3, market value (hereinafter MV) and transformation value (hereinafter TV) in the case of buildable areas coincide: To estimate the MV of a buildable area, it is therefore necessary to use the TV [38-42].

Using the TVM, a buildable area's market value may be accurately and completely obtained by considering both the physical and the juridical/administrative characteristics [43,44]. The TV is analytically estimated using the following formula which represents the TVM Equation:

$$
\mathrm{TV}=\frac{\mathrm{MV}(\mathrm{bl})-\sum \mathrm{Kp}}{\left(1+\mathrm{r}^{\prime}\right)^{\mathrm{n}}} .
$$

To implement the formula that allows a buildable area to be estimated, the MV (bl) (which is to say the MV of the buildable area, provided by the total of MVs of the buildings erected there) and $\sum \mathrm{Kp}$ (or the total costs necessary for the transformation) estimate may be resolved via the collection-from sources of information - of known prices of similar real property.

An area's physical characteristics impact both the MV (bl) and the $\sum \mathrm{kp}$; moreover, if the $\sum \mathrm{kp}$ includes the calculation of the promoter's profit and the initiative's financial interests, the parameter $\mathrm{r}^{\prime}$ becomes a discount coefficient with respect to the area's juridical/administrative characteristics: in sum, it reflects the difficulty and/or uncertainty of completing the area's transformation process due to constraints and limitations requiring more verifications and various authorizations. This discount therefore corresponds with an extra profit for the promoter, commensurate with the risks taken on. Lastly, the parameter $\mathrm{n}$ represents the time coefficient connected with the intervention's duration, which becomes the exponential parameter of the discount.

Therefore, in appraising the value of a POBU area, particular attention must be given to estimating the parameters $\mathrm{r}^{\prime}$ and $\mathrm{n}$, the former depending on the juridical/administrative characteristics and the latter on the times connected with the procedural path (general urban planning instrument, or the implementation plan) attributing the building right.

\subsection{Juridical/Administrative Characteristics (Italian Case)}

In the process of attributing building potential to an area, the juridical/administrative characteristics are manifested in limitations and constraints connoting particular local sensitivities that place 
uncertainties and risk on the positive completion of the process connected with attributing building potentials, once adopted. Taking the Italian case as a reference, an analysis was done on the regulations in force, and the following constraints and limitations were identified (Table 1):

- $\quad$ Landscape constraints (Clc), regulated by Legislative Decree no. 42/2004, in turn, classified as landscape constraints by law $[\mathrm{Clc}(1)]$, declaration constraints $[\mathrm{Clc}(\mathrm{d})]$, constraints as per the landscape plan $[\mathrm{Clc}(\mathrm{p})]$

- Archaeological constraints (Cac), also regulated by Legislative Decree no. 42/2004, direct in type $[\mathrm{Cac}(\mathrm{d})]$.

- Geological protection measures under art. 89 of Presidential Decree no. 380/2001 (Cgm), in turn, dependent upon the seismic zone where the intervention takes place $[\mathrm{Cgm}(\mathrm{h})]$, and mechanical properties of the soil [Cgm(s)]

- $\quad$ Hydro-geological protection limitations and measures (Chm), provided for in the hydro-geological structure instruments prepared pursuant to Law no. 183/1989, in turn, classified as measures and restrictions due to flood hazard $[\mathrm{Chm}(\mathrm{f})]$, and measures and restrictions due to landslide hazard $[\mathrm{Chm}(1)]$.

- $\quad$ Protection measures for vulnerable environmental elements pursuant to Legislative Decree no. 152/2006 (Cem), in turn, classified as measures and restrictions in reserves and protected areas or natural park instituted by Law no. 394/1991 [Cem(p)] or Sites of Community Importance (SCI) instituted with directive 92/43/EEC or Special Protected Areas (SPA) instituted with directive 79/409/EEC [Cem(s)].

Table 1. Constraints and their components in the Italian case.

\begin{tabular}{|c|c|c|c|}
\hline \multicolumn{4}{|c|}{ Constraints and Their Components } \\
\hline \multirow{3}{*}{ Landscape constraints } & \multirow{3}{*}{$\mathrm{Clc}$} & Constraints by law & $\mathrm{Clc}(\mathrm{l})$ \\
\hline & & Declaration constraints & $\mathrm{Clc}(\mathrm{d})$ \\
\hline & & Constraints of the landscape plan & $\mathrm{Clc}(\mathrm{p})$ \\
\hline $\begin{array}{l}\text { Archaeological } \\
\text { constraints }\end{array}$ & $\mathrm{Cac}$ & Direct archaeological constraints & $\operatorname{Cac}(d)$ \\
\hline \multirow{2}{*}{$\begin{array}{l}\text { Geological protection } \\
\text { measures }\end{array}$} & \multirow{2}{*}{ Cgm } & Geological limitations due to seismic hazard & Cgm(h) \\
\hline & & $\begin{array}{l}\text { Geological limitations due to mechanical } \\
\text { properties of poor soil }\end{array}$ & $\operatorname{Cgm}(\mathrm{s})$ \\
\hline \multirow{2}{*}{$\begin{array}{l}\text { Hydro-geological } \\
\text { protection limitations } \\
\text { and measures }\end{array}$} & \multirow{2}{*}{ Chm } & Hydro-geological limitations due to flood hazard & $\operatorname{Chm}(\mathrm{f})$ \\
\hline & & $\begin{array}{l}\text { Hydro-geological limitations due to } \\
\text { landslide hazard }\end{array}$ & $\operatorname{Chm}(\mathrm{l})$ \\
\hline \multirow{2}{*}{$\begin{array}{l}\text { Protection measures for } \\
\text { vulnerable } \\
\text { environmental elements }\end{array}$} & \multirow{2}{*}{ Cem } & Park element present & $\operatorname{Cem}(\mathrm{p})$ \\
\hline & & $\begin{array}{l}\text { SPA/SCI (special protected area/site of community } \\
\text { importance) element present }\end{array}$ & Cem(s) \\
\hline
\end{tabular}

It bears pointing out that, with specific reference to the Italian case, the phase of adoption of general/implementation planning instruments with which the process of attributing a building potential to an area is initiated, can be considered apart from the in-depth examination of all the limitations and/or constraints (competence for which is assigned to specific public authorities) that act upon the chosen area; verification of consistency with higher-order juridical/administrative provisions and with the consequent constraint provisions, the prerogative of the process within the procedure, comes after the adoption phase and before the approval phase enshrining the building right. In general, in the adoption phase, the choices and provisions based on "local" reasons prevail. These include, for example, satisfying residential and non-residential demand, completion of partially urbanized areas regardless of a more complex analysis of the nature of the landscape and of the environment, political consensus; 
and desire to decentralize residential functions and services to strip down urban centers [45,46]. Consequently, building provisions adopted and subject to recurrent taxation, considering the buildable area de facto (even when it is not), during the complex process of approving the urban planning instruments, might be reviewed and even canceled by competent public authorities; in this case, the owner subject to IMU taxation, in accordance with the orientation currently prevailing in Italy, until the final conclusion of the approval process that may even cancel the adopted building provision, is required to pay the tax in relation to the original construction rights conferred by the adopted general urban planning instrument.

\subsection{Times}

The times connected with the conclusion of the process by which a general urban planning instrument is approved, providing for the building potential for given areas, essentially have three phases: (i) adoption; (ii) obtaining of sectoral clearances/opinions (and specifically, those connected with the limitations and/or restrictions derived from the juridical/administrative characteristics); (iii) approval phase.

These times depend closely on the territorial context being worked in $[47,48]$; the proposed historical/assessment approach calls for analyzing a sample of analogous processes concluded in the recent past and in a territorially circumscribed setting, being able to obtain therefrom the various steps that took place, and their duration. Based on the collected data, it becomes possible to make, by analogy, a forecast as to the duration of the administrative process by which a general urban planning instrument that involves attributing building rights is approved.

In Italy, the phases composing the procedural path for the final approval of a GUDP or a GV are generally as follows:

(a) adoption phase.

- $\quad$ adoption of the GUDP/GV by the Municipal Administration by Municipal Council Decision.

- $\quad$ publication of documents.

- submission of observations.

- $\quad$ investigation regarding the observations.

- counter-arguments regarding the observations, and the related Municipal Council Decision.

(b) phase of acquisition of opinions by competent bodies ${ }^{5}$.

- $\quad$ acquisition of all the opinions by the competent local authorities.

- $\quad$ completion of the Strategic Environmental Assessment.

(c) approval phase.

- investigation by the regional offices (where applicable, requests for clarification and additional opinions).

- transmission and corresponding opinion from the Regional Technical Committee for the Territory.

5 Such opinions are routinely: (1) opinion art. 89 of Presidential Decree 380/01 (former art. 13 L.64/74), Regional Council Resolution no. 2694/99 and 545/10; (2) prior ASL opinion art. 20-f L.833/78 and art. 1 Regional Law 52/80; (3) regional opinion art. 2 Regional Law 1/86 Residential Uses; (4) regional landscape opinion; (5) opinion of the Basin Authority responsible in case the affected areas fall within the ideological and hydrogeological risk perimeter; (6) Impact Assessment under Directive 2009/147/EC and 1992/42/EEC "Habitat", as governed by Law 157/1992 and Presidential Decree 357/1997, as amended by Presidential Decree 120/2003; (7) Parks or Nature Reserves management opinion; (8) BB.AA.CC. Ministry opinion local Superintendent; (9) opinions from government departments and public bodies concerned if the planning instrument changes areas and state-owned property (roads, railways, navigation, etc.). 
If approved ( $0 \%$ of the analyzed sample):

- sending of opinion to the Regional Council for its approval decision concluding the proceeding. If approved with modifications ( $100 \%$ of the analyzed sample):

- re-transmission back to the Municipal Administration.

- acceptance of modifications by the Municipal Administration with the council decision, and re-transmission back to the region for the Regional Council's approval decision.

- in the event of non-acceptance or partial acceptance of modifications, Municipal Council decision of counter-argument to the requested modifications and re-transmission back to the region.

- investigation by regional offices of the counter-argument decision, and transmission to the Regional Technical Committee for the territory.

- final opinion of the Regional Technical Committee for the territory and transmission to the Regional Council.

- decision of final approval by the Regional Council, concluding the administrative proceeding.

- publication of the Regional Council's decision in the official regional bulletin, enshrining the final entry into force of the GUDP/GV.

\section{A Model for Determining Influences in the Industrial Performance Rate}

The model was constructed in order to determine a set of parameters, "differentials", or "influences", through which to be able to estimate the specific industrial performance (or discount) rate " $\mathrm{r}$ " for a POBU area being appraised. This is, in sum, a matter of estimating the impact of juridical/administrative characteristics on the rate, or the constraints and limitations, that characterize a POBU area.

The differentials estimated hereafter vary the industrial performance rate which, generally, for territorial transformation interventions, is on the order of $10 \%-25 \%$ [33,34]; in other words, the overall incidence of the constraints and limitations that may be encountered in a POBU area represents what is commonly understood as the "urban planning risk" of a territorial transformation intervention [37].

The estimate of the overall incidence (ico) of these constraints and limitations on the rate is provided by the following formula:

$$
\mathrm{i}_{\mathrm{CO}}=\mathrm{i}_{\mathrm{Clc}}+\mathrm{i}_{\mathrm{Cac}}+\mathrm{i}_{\mathrm{Cgm}}+\mathrm{i}_{\mathrm{Chm}}+\mathrm{i}_{\mathrm{Cem}}
$$

where:

$\mathrm{i}_{\mathrm{CO}}=$ overall incidence of constraints and limitations on the rate.

$\mathrm{i}_{\mathrm{Clc}}=$ incidence of constraint/limitation Clc.

$\mathrm{i}_{\text {Cac }}=$ incidence of constraint/limitation Cac.

$\mathrm{i}_{\mathrm{Cgm}}=$ incidence of constraint/limitation Cgm.

$\mathrm{i}_{\mathrm{Chm}}=$ incidence of constraint/limitation $\mathrm{Chm}$.

$\mathrm{i}_{\mathrm{Cem}}=$ incidence of constraint/limitation Cem.

The incidence of each constraint/limitation depends on the partial incidence ip of the various components of the constraint/limitation.

The incidence of constraint/limitation Clc (landscape constraints) equals:

$$
\mathrm{i}_{\mathrm{Clc}}=\mathrm{d}_{\mathrm{Clc}(1)}+\mathrm{d}_{\mathrm{Clc}(\mathrm{d})}+\mathrm{d}_{\mathrm{Clc}(\mathrm{p})}
$$


where:

$\mathrm{d}_{\mathrm{Clc}(\mathrm{l})}=$ differential due to the component $\mathrm{Clc}(\mathrm{l})$ "landscape constraints by law".

$\mathrm{d}_{\mathrm{Ccl}(\mathrm{d})}=$ differential due to the component $\mathrm{Clc}(\mathrm{d})$ "declaration constraints".

$\mathrm{d}_{\mathrm{Clc}(\mathrm{p})}=$ differential due to the component $\mathrm{Clc}(\mathrm{p})$ "constraints of landscape plan".

The incidence of constraint/limitation Cac (archaeological constraints) equals:

$$
\mathrm{i}_{\mathrm{Cac}}=\mathrm{d}_{\mathrm{Cac}(\mathrm{d})}
$$

where:

$\mathrm{d}_{\mathrm{Cac}(\mathrm{d})}=$ differential due to the component Cac(d) "direct archaeological constraints".

The incidence of constraint/limitation Cgm (geological limitations) equals:

$$
\mathrm{i}_{\mathrm{Cgm}}=\mathrm{d}_{\mathrm{Cgm}(\mathrm{h})}+\mathrm{d}_{\mathrm{Cgm}(\mathrm{s})}
$$

where:

$\mathrm{d}_{\mathrm{Cgm}(\mathrm{h})}=$ differential due to the component $\mathrm{Cgm}(\mathrm{h})$ "geological limitations due to seismic hazard". $\mathrm{d}_{\mathrm{Cgm}(\mathrm{s})}=$ differential due to the component $\mathrm{Cgm}(\mathrm{s})$ "geological limitations due to mechanical properties of poor soil".

The incidence of constraint/limitation Chm (hydro-geological limitations) equals:

$$
\mathrm{i}_{\mathrm{Chm}}=\mathrm{d}_{\mathrm{Chm}(\mathrm{f})}+\mathrm{d}_{\mathrm{Chm}(\mathrm{l})}
$$

where:

$\mathrm{d}_{\mathrm{Chm}(\mathrm{f})}=$ differential due to the component $\mathrm{Chm}(\mathrm{f})$ "hydro-geological limitations due to flood hazard". $\mathrm{d}_{\mathrm{Chm}(\mathrm{l})}=$ differential due to the component $\mathrm{Chm}(\mathrm{l})$ "hydro-geological limitations due to landslide hazard".

The incidence of constraint/limitation Cem (elements of environmental vulnerability) equals:

$$
\mathrm{i}_{\mathrm{Cem}}=\mathrm{d}_{\mathrm{Cem}(\mathrm{p})}+\mathrm{d}_{\mathrm{Cem}(\mathrm{s})}
$$

where:

$\mathrm{d}_{\mathrm{Cem}(\mathrm{p})}=$ differential due to the component $\operatorname{Cem}(\mathrm{p})$ "park element present".

$\mathrm{d}_{\mathrm{Cem}(\mathrm{s})}=$ differential due to the component Cem(s) "SPA/SCI (special protected area/site of community importance) element present".

The overall incidence is therefore provided by the sum of the incidence of each of the constraints/limitations which, in their turn, are provided by the sum of the differentials of each of their components.

It therefore becomes necessary to estimate, for each constraint/limitation, the differential of each of its components through the following inverse power function in equation:

$$
\mathrm{dcx}_{(\mathrm{x})}=\sqrt[t]{\Delta\left[\mathrm{Cx}_{(\mathrm{x})}\right]_{\mathrm{n}}}-1
$$

where:

$\mathrm{dCx}_{(\mathrm{x})}=$ differential of the component $\mathrm{x}$ of constraint/limitation $\mathrm{x}$. 
$\Delta\left[\left(\mathrm{Cx}_{(\mathrm{x})}\right]_{\mathrm{n}}=\right.$ difference of value relating to survey sample $\mathrm{n}$, between a buildable area without the limitation as per component $x$ of constraint/limitation $C x$ and a buildable area with the limitation as per component $x$ of the same constraint/limitation.

$\mathrm{t}=$ the presumed number of years for the completion of the settlement transformation, to be estimated also in accordance with the proposed approach (see paragraph 3.3);

The survey sample therefore consists of data related to the value (expressed via the known price) of two similar areas, in a homogeneous territorial context, that are differentiated only by a component of a constraint/limitation.

It is therefore possible to estimate $\Delta\left[\mathrm{Cx}_{(\mathrm{x})}\right]_{\mathrm{n}}$ using the following equation:

$$
\Delta\left[\mathrm{Cx}_{(\mathrm{x})}\right]_{\mathrm{n}}=\operatorname{Pnl}\left[\mathrm{Cx}_{(\mathrm{x})}\right]_{\mathrm{n}} / \operatorname{Pwl}\left[\mathrm{Cx}_{(\mathrm{x})}\right]_{\mathrm{n}}
$$

where:

$\mathrm{Pnl}_{\mathrm{n}}=$ is the known price of a buildable area without limitations.

$\mathrm{Pwl}_{n}=$ is the known price of a buildable area with the limitation as per the component $\mathrm{Cx}_{(\mathrm{x})}$.

The condition for being able to consider the survey sample valid is for $\mathrm{Pnl}_{\mathrm{n}}$ to be less than $\mathrm{Pwl}_{\mathrm{n}}$; otherwise, the solution is out of the ordinary and the datum is not considered.

Considering a non-defined number of survey samples, Equation (8) becomes equation:

$$
\mathrm{dCx}_{(\mathrm{x})}=\sqrt[t]{\left.\left\{\frac{\operatorname{Pnl}\left[\mathrm{Cx}_{(\mathrm{x})}\right]_{1}}{\operatorname{Pwl}\left[\mathrm{Cx}_{(\mathrm{x})}\right]_{1}}+\frac{\operatorname{Pnl}\left[\mathrm{Cx}_{(\mathrm{x})}\right]_{2}}{\operatorname{Pwl}\left[\mathrm{Cx}_{(\mathrm{x})}\right]_{2}}+\ldots+\frac{\operatorname{Pnl}\left[\mathrm{Cx}_{(\mathrm{x})}\right]_{\mathrm{n}}}{\operatorname{Pwl}\left[\mathrm{Cx}_{(\mathrm{x})}\right]_{\mathrm{n}}}\right\} / \mathrm{n}\right)}-1 .
$$

For the model's implementation, it therefore becomes necessary:

- To obtain a significant number of survey samples, or known prices of homogenous buildable areas.

- To apply Equation (10) for the estimate of the differentials of each component of each relevant variable.

Lastly, considering, then, that the industrial performance rate is provided by the sum of the differentials due to the component of the constraints/limitations in equation:

$$
\mathrm{r}^{\prime}=\mathrm{i}_{\mathrm{CO}}=\mathrm{d}_{1}+\mathrm{d}_{2}+\cdots+\mathrm{d}_{\mathrm{n}}
$$

it is possible, having implemented the model and obtained the results relating to the incidences, to estimate $r^{\prime}$ as follows from equation:

$$
\mathrm{r}^{\prime}=\mathrm{d}_{\mathrm{Clc}(1)}+\mathrm{d}_{\mathrm{Clc}(\mathrm{d})}+\mathrm{d}_{\mathrm{Clc}(\mathrm{p})}+\mathrm{d}_{\mathrm{Cac}(\mathrm{d})}+\mathrm{d}_{\mathrm{Cgm}(\mathrm{h})}+\mathrm{d}_{\mathrm{Cgm}(\mathrm{s})}+\mathrm{d}_{\mathrm{Chm}(\mathrm{f})}+\mathrm{d}_{\mathrm{Chm}(1)}+\mathrm{d}_{\mathrm{Cem}(\mathrm{p})}+\mathrm{d}_{\mathrm{Cem}(\mathrm{s})} \text {. }
$$

Equation (12) represents nothing more than the sum of the different incidences in equation:

$$
\mathrm{r}^{\prime}=\sum_{k=0}^{n} \mathrm{~d}
$$

From the sum of Equation (13), $\mathrm{r}^{\prime}$, an element essential for estimating the value of a POBU area, may then be estimated. 


\section{Application of the Model: Definition of a Set of Influences for the Definition of $\mathbf{r}^{\prime}$ for POBU Areas}

\subsection{Gathering of Data and Implementation of the Model}

The model structured in paragraph 4 above was operatively tested to define the incidences of juridical/administrative characteristics such as components of parameter $\mathrm{r}^{\prime}$, taking the northern territory of the Province of Rome as an investigation setting.

In this regard, research was done on sale prices of residentially zoned buildable areas (GUDP/GV approved) but still without approved implementation instruments, and consequently without building permits. These data refer to areas yet to be urbanized.

The difficulty connected with obtaining a considerable and articulated number of data resulted in extending the data search field over territory and time, with this choice being deemed admissible since:

Although generally varying the values of buildable areas, with regard to the municipalities and the zones where they are located, it bears pointing out that the differentials that are generated with respect to juridical/administrative characteristics are independent of the position, since they reflect, as argued earlier, increased profit for the promoter, depending on the greater risk taken on in comparison with ordinary risk conditions. For this reason, it is held that, for the purposes of this experimentation, incidences may be defined by considering an investigative sample territorially expanded to a sector (north) of an entire province, provided that, for each individual calculation, each Pnl/Pwl comparison is made with data pertaining to the same municipality.

Although the real estate market presents oscillations that are generally measured with a yearly frequency, the investigation was extended to sales taking place from 2017 to date; considering that, using the proposed model, discount parameters relating to a juridical/administrative characteristics must be sought, this extension over time is admissible under the condition that each Pnl/Pwl be performed with temporarily proximate data.

In this research, 98 data points referred to "trades" of land were observed; within this data stock, there are different types of land: Actual buildable areas without constraints or with one or more constraints and POBU areas without constraints or with one or more constraints. Furthermore, the areas have different classifications by GUDP/GV: residential, commercial, touristic, services, and artisan-productive. Among these 98 data points, 20 data points are usable according to the proposed model (referred to two similar areas, in a homogeneous territorial context, that are differentiated only by a component of a constraint/limitation).

Table 2 reports the data (20 among 98) that were found and used to implement the model; Table 3 reports a sample of data ( 10 among 98$)$ that were found but are not usable; the only purpose of Tables 2 and 3 are to show how overlapped constraints generate lower unit prices.

Based on the albeit limited data, the proposed model was implemented. For each relevant variable, the differentials of the various diverse components were calculated using Equation (10). By convention, a three-year period (see paragraph 5.2) is considered for concluding the approval proceedings of the PRGs in the municipalities taken as reference.

With regard to the "constraints by law" component, the following is obtained (applying Equation (10)):

$$
\mathrm{d}_{\mathrm{Clc}(1)}=\sqrt[3]{\left\{\left(\frac{135}{110}+\frac{141}{131}\right) / 2\right\}}-1=4.82 \%
$$

Similarly, Equation (10) has been applied to obtain $\mathrm{r}^{\prime}$ for each limitation/constraint identified (Table 4). Section 5.2 summarizes the results of the application; it is configured as a table overviewing the differentials of the various components of the relevant variables on the discount rate to be applied in the estimate of a POBU area. 
Table 2. Data collection for the application of the model.

\begin{tabular}{|c|c|c|c|c|c|}
\hline Id. & $\begin{array}{c}\text { Municipality } \\
\text { (Province of Rome) }\end{array}$ & $\begin{array}{l}\text { Building } \\
\text { Potential }\end{array}$ & Sale Price & Unit Sale Price & Constraint \\
\hline & & $\mathrm{m}^{3}$ & $€$ & $€ / \mathrm{m}^{2}$ & \\
\hline $\mathrm{Pnl}_{1 \cdot \mathrm{AS}}$ & Angillara Sabazia & 2365 & 320,000 & 135 & No constraints \\
\hline $\operatorname{Pwl}\left[\mathrm{Clc}_{(1)}\right]_{1 . A S}$ & Angillara Sabazia & 5740 & 630,000 & 110 & Clc-Constraint by law \\
\hline $\mathrm{Pwl}\left[\mathrm{Clc}_{(\mathrm{d})}\right]_{1 . \mathrm{AS}}$ & Angillara Sabazia & 2000 & 250,000 & 125 & Clc-Declaration constraint \\
\hline $\operatorname{Pwl}\left[\mathrm{Cl}_{(\mathrm{p})}\right]_{1 . A S}$ & Angillara Sabazia & 3260 & 410,000 & 126 & Landscape - Constraints of the landscape plan \\
\hline Pnl.BR & Bracciano & 925 & 130,000 & 141 & No constraint \\
\hline $\operatorname{Pwl}\left[\mathrm{Clc}_{(1)}\right]_{1 . \mathrm{BR}}$ & Bracciano & 800 & 105,000 & 131 & Clc-Constraints by law \\
\hline $\operatorname{Pwl}\left[\mathrm{Cem}_{(\mathrm{p})}\right]_{1 . \mathrm{BR}}$ & Bracciano & 9600 & $1,295,000$ & 135 & Cem-Park element present (zone B) \\
\hline $\operatorname{Pwl}\left[\mathrm{Gpm}_{(\mathrm{s})}\right]_{1 . \mathrm{BR}}$ & Bracciano & 6210 & 655,000 & 105 & $\begin{array}{c}\text { Gpm-Geological limitations due to mechanical } \\
\text { properties of poor soil }\end{array}$ \\
\hline $\mathrm{Pnl}_{1 . \mathrm{TR}}$ & Trevignano Romano & 400 & 66,000 & 165 & No constraints \\
\hline $\operatorname{Pwl}\left[\mathrm{Cem}_{(\mathrm{p})}\right]_{1 . \mathrm{TR}}$ & Trevignano Romano & 1968 & 290,000 & 147 & Cem-Park element present (zone B) \\
\hline $\operatorname{Pwl}\left[\mathrm{Cem}_{(\mathrm{p})}\right]_{2 . \mathrm{TR}}$ & Trevignano Romano & 1600 & 230,000 & 144 & Cem-Park element present (zone B) \\
\hline $\operatorname{Pwl}\left[\mathrm{Cem}_{(\mathrm{s})}\right]_{1 . \mathrm{TR}}$ & Trevignano Romano & 550 & 70,000 & 127 & Cem-SPA element present \\
\hline $\operatorname{Pwl}\left[\mathrm{Cem}_{(\mathrm{s})}\right]_{2 . \mathrm{TR}}$ & Trevignano Romano & 370 & 45,000 & 122 & Cem—SPA element present \\
\hline Pnl.1.CE & Cerveteri & 2275 & 310,000 & 136 & No constraints \\
\hline $\operatorname{Pwl}\left[\mathrm{Cac}_{(\mathrm{d})}\right]_{1 . \mathrm{CE}}$ & Cerveteri & 1800 & 170,000 & 94 & Cac-Direct archaeological constraints \\
\hline 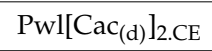 & Cerveteri & 1200 & 118,000 & 98 & Cac-Direct archaeological constraints \\
\hline 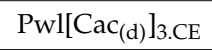 & Cerveteri & 780 & 78,000 & 100 & Cac-Direct archaeological constraints \\
\hline $\operatorname{Pwl}\left[\mathrm{Clc}_{(\mathrm{d})}\right]_{1 . C E}$ & Cerveteri & 850 & 110,000 & 129 & Clc-Declaration constraints \\
\hline $\operatorname{Pwl}\left[\mathrm{Gpm}_{(\mathrm{s})}\right]_{1 . \mathrm{CE}}$ & Cerveteri & 1100 & 110,000 & 100 & $\begin{array}{l}\text { Gpm-Geological limitations due to mechanical } \\
\text { properties of poor soil }\end{array}$ \\
\hline $\mathrm{Pnl}_{1 . \mathrm{LA}}$ & Ladispoli & 5890 & 950,000 & 161 & No constraints \\
\hline $\operatorname{Pwl}\left[\mathrm{Chm}_{(\mathrm{f})}\right]_{1 . \mathrm{LA}}$ & Ladispoli & 3580 & 490,000 & 137 & $\begin{array}{l}\text { Chm-Hydro-geological limitations due to flood hazard } \\
\text { (from Hydro-geological Order Plan) }\end{array}$ \\
\hline $\operatorname{Pwl}\left[\mathrm{Clc}_{(\mathrm{p})}\right]_{1 . \mathrm{LA}}$ & Ladispoli & 5920 & 830,000 & 140 & Landscape - Constraints of the landscape plan \\
\hline $\mathrm{Pnl}_{1 . \mathrm{SM}}$ & Santa Marinella & 3100 & 460,000 & 148 & No constraints \\
\hline $\operatorname{Pwl}\left[\mathrm{Chm}_{(\mathrm{f})}\right]_{1 . S M}$ & Santa Marinella & 570 & 80,000 & 140 & $\begin{array}{l}\text { Chm-Hydro-geological limitations due to flood hazard } \\
\text { (from Hydro-geological Order Plan) }\end{array}$ \\
\hline
\end{tabular}


Table 3. Sample of data collection found but not usable.

\begin{tabular}{|c|c|c|c|c|c|}
\hline Id. & $\begin{array}{c}\text { Municipality } \\
\text { (Province of Rome) }\end{array}$ & $\begin{array}{l}\text { Building } \\
\text { Potential }\end{array}$ & Sale Price & Unit Sale Price & Constraint \\
\hline & & $\mathrm{m}^{3}$ & $€$ & $€ / \mathrm{m}^{2}$ & \\
\hline Not used 1 & Angillara Sabazia & 4520 & 325,000 & 72 & $\begin{array}{c}\text { Clc-Constraint by law, Gpm-Geological limitations } \\
\text { due to mechanical properties of poor soil }\end{array}$ \\
\hline Not used 2 & Angillara Sabazia & 4555 & 346,000 & 76 & $\begin{array}{c}\text { Clc-Constraint by law, Gpm-Geological limitations } \\
\text { due to mechanical properties of poor soil }\end{array}$ \\
\hline Not used 3 & Bracciano & 8754 & 860,000 & 98 & $\begin{array}{l}\text { Gpm-Geological limitations due to mechanical } \\
\text { properties of poor soil; Cem-Park element present } \\
\text { (zone B) }\end{array}$ \\
\hline Not used 4 & Bracciano & 7877 & 750,000 & 95 & $\begin{array}{l}\text { Gpm-Geological limitations due to mechanical } \\
\text { properties of poor soil; Cem-Park element present } \\
\text { (zone B) }\end{array}$ \\
\hline Not used 5 & Bracciano & 2125 & 205,000 & 96 & $\begin{array}{l}\text { Gpm-Geological limitations due to mechanical } \\
\text { properties of poor soil; Cem-Park element present } \\
\text { (zone B) }\end{array}$ \\
\hline Not used 6 & Cerveteri & 4250 & 380,000 & 90 & $\begin{array}{l}\text { Landscape-Constraints of the landscape plan; } \\
\text { Cac-Direct archaeological constraints }\end{array}$ \\
\hline Not used 7 & Cerveteri & 4260 & 380,000 & 90 & $\begin{array}{l}\text { Landscape-Constraints of the landscape plan; } \\
\text { Cac-Direct archaeological constraints }\end{array}$ \\
\hline Not used 8 & Trevignano Romano & 2690 & 247,500 & 92 & $\begin{array}{l}\text { Clc - Constraints by law; Cem-Park element present } \\
\text { (zone B) }\end{array}$ \\
\hline Not used 9 & Trevignano Romano & 2726 & 240,000 & 88 & $\begin{array}{l}\text { Clc-Constraints by law; } \mathrm{Cem}-\text { Park element present } \\
\text { (zone B) }\end{array}$ \\
\hline Not used 10 & Trevignano Romano & 2876 & 245,000 & 85 & $\begin{array}{l}\mathrm{Clc}-\text { Constraints by law; } \mathrm{Cem} \text {-Park element present } \\
\text { (zone B) }\end{array}$ \\
\hline
\end{tabular}


Table 4. Application results.

\begin{tabular}{|c|c|c|}
\hline \multicolumn{2}{|c|}{ Constraints and Components } & $d_{n}$ \\
\hline \multirow{3}{*}{ Landscape } & Constraints by law & $4.82 \%$ \\
\hline & Declaration constraints & $2.21 \%$ \\
\hline & Constraints of the landscape plan & $3.64 \%$ \\
\hline Archaeological constraints & Direct archaeological constraints & $11.79 \%$ \\
\hline \multirow{2}{*}{ Geological protection measure } & $\begin{array}{l}\text { Geological limitations due to } \\
\text { seismic hazard }\end{array}$ & NA \\
\hline & $\begin{array}{l}\text { Geological limitations due to } \\
\text { mechanical properties of poor soil }\end{array}$ & $9.72 \%$ \\
\hline \multirow{2}{*}{$\begin{array}{l}\text { Hydro-geological protection } \\
\text { limitations and measures }\end{array}$} & $\begin{array}{l}\text { Hydro-geological limitations due } \\
\text { to flood hazard }\end{array}$ & $3.78 \%$ \\
\hline & $\begin{array}{l}\text { Hydro-geological limitations due } \\
\text { to landslide hazard }\end{array}$ & NA \\
\hline \multirow{2}{*}{$\begin{array}{l}\text { Protection measures for vulnerable } \\
\text { environmental elements }\end{array}$} & Park element present & $3.33 \%$ \\
\hline & SPA/SCI element present & $9.88 \%$ \\
\hline
\end{tabular}

Note: $d_{n}$ represents the differential of $r^{\prime}$ which depends on constraints and components (see Equation (11)).

\subsection{Historical/Assessment Approach for the Estimate of the Times}

The historical/assessment approach for the estimate of the times needed for the approval of a PRG/VG was made operative by means of an analysis conducted taking as a reference the procedural paths of a sample of 59 GUDP/GVs concluded in the Lazio Region (Provinces of Rome, Rieti, and Viterbo) from 2000 to 2018.

The study of the $59 \mathrm{GUDP} / \mathrm{GV}$ s procedures taken as a survey sample was further deepened with the purpose of determining the times needed to carry out the various phases in the approval procedure, thus being able to define the average duration of the procedural path.

The complexity of the procedural path for approving GUDP/GV causes lengthy times for achieving definitive approval; an overall duration of the path, from adoption to approval, of about seven years, emerges.

It bears pointing out that for each of the phases referred to above, that entails a specific decision document by the municipal administration, debate is needed (particularly in medium/large municipalities) of the measure and of its contents in the competent council commissions, with the consequent lengthening of the times for concluding the procedural path.

The analysis that was done shows that the municipalities taken as reference in the previous paragraph require 2 to 4 years in order to be able to complete their authorization path for approving their GVs; for the sake of simplifying the application, a conventional period for completing the procedural path for approving the GUDP/GV equal to 3 years is assumed.

For the purpose of determining the parameter $\mathrm{n}$ to be used in the TVM, consideration should be taken-in addition to the time component derived from the period necessary for the approval of the GUDP/GV with which the POBU area becomes a buildable area to all purposes—of the time component due to the completion of the initiative to transform the POBU area (permits, construction, marketing); this second component, although depending on the construction processes put in place and on the market conditions determining the greater or lesser ease of selling the real assets that are produced, in line with appraisal practice [49], may be considered as having an average duration of 3 years. 
In light of this:

$$
\mathrm{n}=\mathrm{n}^{\prime}+\mathrm{n}^{\prime \prime}
$$

where:

$\mathrm{n}^{\prime}=$ times for completing the GUDP/GV approval procedures.

$\mathrm{n}^{\prime \prime}=$ times for completing the construction transformation intervention.

Therefore, the MV of a buildable area (actual or POBU) must be assessed considering the timing to complete the real estate initiative implementable on the same area: 3 years for an actual buildable land (in approved GUDP/GV); 6 years for POBU areas (in adopted GUDP/GV).

\subsection{Results and Their Use: A Practical Example}

This paragraph intends to represent, in exclusively operative and practical terms, the potential derived from applying the proposed model. What the brief application proposed aims to make visible is that implementation of the TVM, for POBU areas, not considering their characteristics through previously discussed assessment parameters, would yield results leveled and without variation even among areas with greatly different characteristics.

The results obtained with the experimentation of the model and contained in Table 3 yield an overall picture regarding the incidence of the components of the relevant variables on the industrial performance rate:

- $\quad$ By representing "limitations" of a buildable area, they produce, historically and ordinarily, a diminishment of its value.

- As components of the industrial performance rate, when an expression of extra profits alone (the ordinary profit is considered directly among the indirect "costs" of the intervention), this is configured as gain that is manifested by discounting the value of a buildable area in relation to its "limits".

It bears pointing out, however, that the data refer to situations with a single limitation and constraint; there are, however, situations in which a POBU area may present overlapping constraints and limitations. The obtained results show that a POBU area presenting overlapping conditions of limitations and/or constraint is subject to significant limitations of value.

To provide evidence of the significance of the obtained results, the following practical example is proposed.

Consider three areas with the same physical characteristics (yielding the same revenues and the same construction costs) but with different juridical/administrative characteristics:

(1) The first area, without constraints, immediately buildable by virtue of the presence of a building permit ( 3 years have been considered for the land urbanization, built construction, and the sale of properties built).

(2) The second area, POBU, without constraints, with at least a three-year wait prior to concluding the procedural path connected to its actual buildability ( 3 years have been considered for the approval of the GUDP/GV; a further 3 years have been considered for the land urbanization, built construction, sell properties built).

(3) The third area, POBU, with the following constraints: landscape constraint by law, flood hazard, and inclusion within a nature reserve (zone B of Park), with at least a three-year wait prior to concluding the procedural path connected to its actual buildability (6 years have been considered, the same for area 2).

The times for completing the construction intervention equal one year after the start of the works.

Market value for the buildings to be built equal to $€ 3000$ per square meter (sqm) built, production expenses, including profit, interest, and all else necessary for producing the building asset, equal 
to $€ 1500$ per sqm is hypothesized. Even considering that the industrial performance rate should be accurately assessed [33], a rate equal to $3 \%$ is hypothesized as capital cost (Eurirs/Euribor assumed as $0.50 \%$ plus spread assumed as $2.50 \%$ ).

The unit market value (per sqm of buildable area) for the three areas is estimated.

The first area will have a unit market value equal to:

$$
\text { MVarea } 1=\frac{€ 3.000-€ 1.500}{(1+0.03)^{3}}=€ 1.373 \text { (per sqm buildable). }
$$

The second area will have a unit market value equal to:

$$
\text { MVarea } 2=\frac{€ 3.000-€ 1.500}{(1+0.03)^{6}}=€ 1.256 \text { (per sqm buildable). }
$$

The third area will have a unit market value equal to:

$$
\text { MVarea } 3=\frac{€ 3.000-€ 1.500}{[1+(0.03+0.0482+0.0378+0.0333)]^{6}} .=€ 648 \text { (per smq buildable) }
$$

Lacking this estimation reasoning, given the current practice in the area of recurrent taxation of POBU areas, the three areas are considered as of equal value and are therefore subject to the same taxable base for IMU purposes.

\section{Conclusions}

The use of the TVM, along with the proposed method, allows a POBU area to be appraised as it is, contemplating presumable time and risk before the actual condition of buildability is juridically enshrined with the approval of the corresponding general urban planning instrument.

In sum, the proposed innovation consists of estimating the "urban planning risk" component of $r$ " using the build model, and defining the times using the proposed historical/assessment approach.

The model, starting from simple data referring to specific situations, made it possible to determine influences in the rate of industrial profitability rate correlated with the urban planning risk of POBU areas; these influences may have a broader validity in territorial terms since, from one territorial environment to another, it is held that the "effects" produced by the so/called "limitations" - in terms of reducing the areas' value-are substantially analogous: in this sense, the incidences, once defined, have a broad field of action.

However, during the model's implementation, a general difficulty emerged in the search for data suitable for its implementation; the model requires data referring to areas that differ from one another for a single juridical/administrative characteristic; for 98 examined data points, only 20 were of use, yielding a percentage equal to approximately $20 \%$ of useful data points.

The experimentation still results in finding that, even with few data, stable results can be achieved.

Analysis of the problem showed how further examination may be structured on linear or multiple regression models, being able in this way to process data referring to areas that present several constraints/limitations at the same time; using regression models, the number of usable data points (20 in the previous application of proposed model) can be increased.

The proposed approach, if repeated regularly (yearly, in correspondence with the formation of the taxable bases to be subjected to taxation) allows POBU areas to be attributed a value as a taxable base that is fair and current, thereby overcoming the conflicting case law and the problems derived from unfair taxation of these POBU areas.

Author Contributions: Conceptualization, F.B., O.C. and F.F.; Data curation, F.B., O.C. and F.F.; Formal analysis, F.B., O.C. and F.F.; Funding acquisition, O.C.; Investigation, F.B., O.C. and F.F.; Methodology, F.B., O.C. and F.F.; Project administration, F.B., O.C. and F.F.; Resources, F.B., O.C. and F.F.; Software, F.B.; Supervision, F.B.; Validation, 
F.B., O.C. and F.F.; Visualization, F.B., O.C. and F.F.; Writing—original draft, F.B.; Writing—review \& editing, F.B. All authors have read and agreed to the published version of the manuscript.

Funding: This research was funded by Sapienza University of Rome, granted by "Research Project", 2019, The APC was funded by Sapienza University of Rome, granted by "Research Project", 2019.

Conflicts of Interest: The authors declare no conflict of interest.

\section{References}

1. Assini, N.; Mantini, P. Manuale di Diritto Urbanistico (Terza Edizione); Giuffrè Editore: Milan, Italy, 2007.

2. Bottero, M.; Mondini, G. Assessing socio-economic sustainability of urban regeneration programs: An integrated approach. In Smart and Sustainable Planning for Cities and Regions; Springer International Publishing: Cham, Switzerland, 2017; pp. 165-184. [CrossRef]

3. Forte, F. Appraisal and evaluation in the production of works for the transformation of the contemporary city. In Appraisal: From Theory to Practice: Results of SIEV 2015; Springer International Publishing: Cham, Switzerland, 2017; pp. 129-138. [CrossRef]

4. Battisti, F.; Campo, O. The Appraisal of Buildable Land for Property Taxation in the Adopted General Municipal Plan. In Proceedings of the Computational Science and Its Applications-ICCSA 2016: 16th International Conference, Beijing, China, 4-7 July 2016; pp. 22-32. [CrossRef]

5. European Central Bank. Asset Quality Review_Phase 2 Manual; European Central Bank: Frankfurt, Germany, 2014; ISBN 978-92-899-1254-9.

6. Sdino, L.; Rosasco, P.; Torrieri, F.; Oppio, A. Smart Innovation, Systems and Technologies. A mass appraisal model based on multi-criteria evaluation: An application to the property portfolio of the bank of Italy. In New Metropolitan Perspectives; Calabrò, F., Della Spina, L., Bevilacqua, C., Eds.; Springer: Cham, Switzerland, 2019; Volume 100. [CrossRef]

7. Agenzia delle Entrate-Osservatorio del Mercato Immobiliare. Quaderni dell'Osservatorio. In Appunti di Economia Immobiliare; Agenzia delle Entrate-Osservatorio del Mercato Immobiliare: Rome, Italy, 2014.

8. AGN International. Gift and Inheritance Tax-A European Comparison; AGN website: London, UK, 2014.

9. Nesticò, A.; Sica, F. The sustainability of urban renewal projects: A model for economic multi-criteria analysis. J. Prop. Invest. Financ. 2017, 35, 397-409. [CrossRef]

10. Forte, F. Valore della città e rendite urbane. In La Città Che si Rinnova. Architettura e Scienze Umane tra Storia e Attualità: Prospettive di Analisi a Confronto; Manzo, E., Ed.; Franco Angeli: Milano, Italy, 2012.

11. IVSC. Proposed New International Valuation Standards; IVSC: London, UK, 2010.

12. European Commission. Annual Growth Survey; European Commission: Brussels, Belgium, 2013.

13. European Commission. Tax Reforms in EU Member States 2014. In Tax Policy Challenges for Economic Growth and Fiscal Sustainability; European Economy; DGEFA: Brussels, Belgium, 2014.

14. Garnier, G.; György, E.; Heineken, K.; Mathé, M.; Puglisi, L.; Ruà, S.; Van Mierlo, A. A wind of change? Reforms of Tax Systems since the launch of Europe 2020. Boeck Supérieur 2015, 53, 75-111. [CrossRef]

15. Kneller, R.; Bleaney, M.F.; Gemmell, N. Fiscal policy and growth: Evidence from OECD countries. J. Public Econ. 1999, 74, 171-190. [CrossRef]

16. Mirrlees, J.; Adam, S. Tax by Design: The Mirrlees Review; Oxford University Press: Oxford, UK, 2011; Volume 2.

17. Piketty, T.; Saez, E. Top Incomes and the Great Recession: Recent Evolutions and Policy Implications. In Proceedings of the 13th Jacques Polak Annual Research Conference Hosted by the International Monetary Fund, Washington, DC, USA, 8-9 November 2012.

18. Profeta, P.; Scabrosetti, S.; Winer, S.L. Wealth transfer taxation: An empirical investigation. Int. Tax Public Financ. 2014, 21, 720-767. [CrossRef]

19. Andrews, D. Real House Prices in OECD Countries: The Role of Demand Shocks and Structural and Policy Factors. In OECD Economics Department Working Papers; OECD Publishing: Paris, France, 2010.

20. Arrondel, L.; Masson, A. Taxing More (Large) Family Bequests: Why, When, Where; Paris School of Economics: Paris, France, 2013.

21. Atkinson, A.B.; Piketty, T.; Saez, E. Top Incomes in the Long Run of History. J. Econ. Lit. 2011, 49, 3-71. [CrossRef]

22. Bertocchi, G. The Vanishing Bequest Tax: The Comparative Evolution of Bequest Taxation in Historical Perspective; Economics \& Politics: Hoboken, NJ, USA, 2011; Volume 23, pp. 107-131. 
23. Ribera, F.; Nesticò, A.; Cucco, P.; Maselli, G. A multicriteria approach to identify the Highest and Best Use for historical buildings. J. Cult. Herit. 2019. [CrossRef]

24. European Commission. The EU compendium of spatial planning systems and policies. In Directorate-General for Regional and Urban Policy; European Commission: Brussels, Belgium, 1999.

25. Stanghellini, S. Il Negoziato Pubblico Privato nei Progetti Urbani. Principi, Metodi e Tecniche di Valutazione; DeI: Rome, Italy, 2012.

26. Micelli, E. Five issues concerning urban plans and the transfer of development rights. [Cinque problemi intorno a perequazione, diritti edificatori e piani urbanistici]. Sci. Reg. 2014, 13, 9-27.

27. Guarini, M.R.; Battisti, F. Benchmarking multi-criteria evaluation methodology's application for the definition of benchmarks in a negotiation-type public-private partnership. A case of study: The integrated action programmes of the Lazio Region. Int. J. Bus. Intell. Data Min. 2014, 9, 271-317. [CrossRef]

28. Regione Lazio. La Pianificazione Nel Territorio Comunale. Available online: http://www.regione.lazio.it/rl_ urbanistica/?vw=contenutiDettaglio\&id=46 (accessed on 4 December 2019).

29. Senato della Repubblica Italiana. Aggiornamento Della Nota Metodologica e Della Stima Della Capacità Fiscale 2018 per i Comuni Delle Regioni a Statuto Ordinario. Atto del Governo 438. Available online: http://www.senato.it/service/PDF/PDFServer/BGT/01044432.pdf (accessed on 4 December 2019).

30. Royal Institution of Chartered Surveyors. RICS Appraisal and Valuation Standards; RICS: London, UK, 2017.

31. European Group of Valuers' Associations (TEGoVA). European Valuation Standards_EVS 2016; Gillis nv/sa: Brussels, Belgium, 2016.

32. Giammaria, V.; Bambagioni, G.; Simonotti, M. Tecnoborsa, E Associazione Bancaria Italiana (2018) Codice Delle Valutazioni Immobiliari: Italian Property Valuation Standard; Tecnoborsa: Roma, Italy, 2018.

33. Battisti, F.; Campo, O. A methodology for determining the profitability index of real estate initiatives involving public-private partnerships. A case study: The integrated intervention programs in Rome. Sustainability 2019, 11, 1371. [CrossRef]

34. Battisti, F.; Campo, O. A Procedure for Determining the Industrial Profitability of Settlement Interventions in the Appraisal of Exceptional Contribution of Urbanization. In Proceedings of the 18th International Conference, Melbourne, Australia, 2-5 July 2018. [CrossRef]

35. Micelli, E. Enabling real property. how public real estate assets can serve urban regeneration. Territorio 2019, 87, 93-97. [CrossRef]

36. Giudice, V.D.; De Paola, P.; Forte, F. Using genetic algorithms for real estate appraisals. Buildings 2017, 7, 31. [CrossRef]

37. Capolongo, S.; Sdino, L.; Dell'Ovo, M.; Moioli, R.; Della Torre, S. How to assess urban regeneration proposals by considering conflicting values. Sustainability 2019, 11, 3877. [CrossRef]

38. Forte, C.; De Rossi, B. Principi di Economia ed Estimo; Etas: Milano, Italy, 1974.

39. Roscelli, R. Manuale di Estimo. Esercizio Della Professione; UTET Universitaria: Milano, Italy, 2014.

40. Simonotti, M. Metodologia estimativa. In Metodi di stima immobiliare. Applicazione Degli Standard Internazionali; Dario Flaccovio: Palermo, Italy, 2006; pp. 1-423.

41. Orefice, M.; Orefice, L. Estimo Civile; Utet Università: Turin, Italy, 2014.

42. Acampa, G.; Giuffrida, S.; Napoli, G. Appraisals in Italy Identity, Contents, Prospects | [La Disciplina Estimativa in Italia Identità, Conoscenza, Prospettive]- Valori e Valutazioni; DEI: Rome, Italy, 2018; pp. 13-32.

43. Campo, O. Appraisal of the Extraordinary Contribution in General Regulatory Plan of Rome. Int. J. Math. Models Methods Appl. Sci. 2015, 9, 404-409.

44. Oppio, A.; Torrieri, F.; Bianconi, M. Land value capture by urban development agreements: The case of Lombardy region (Italy). Smart Innov. Syst. Technol. 2019, 346-353. [CrossRef]

45. Della Spina, L.; Calabrò, F. Decision Support Model for Conservation, Reuse and Valorization of the Historic Cultural Heritage. In Computational Science and Its Applications-ICCSA 2018; Gervasi, O., Murgante, B., Misra, S., Stankova, E., Torre, C.M., Rocha, A.M.A.C., Taniar, D., Apduhan, B.O., Tarantino, E., Ryu, Y., Eds.; Springer: Cham, Switzerland, 2018; Volume 10962. [CrossRef]

46. Della Spina, L. A Multi-level Integrated Approach to Designing Complex Urban Scenarios in Support of Strategic Planning and Urban Regeneration. In New Metropolitan Perspectives. ISHT 2018; Calabrò, F., Della Spina, L., Bevilacqua, C., Eds.; Springer: Cham, Switzerland, 2019; Volume 100. [CrossRef]

47. Bostenaru Dan, M. Decision Making Based on Benefit-Costs Analysis: Costs of Preventive Retrofit versus Costs of Repair after Earthquake Hazards. Sustainability 2018, 10, 1537. [CrossRef] 
48. Manzone, F.; Rebaudengo, M.; Zaccaro, V.L. The Italian response to sustainability in built environment: The match between law and technical assessment. Adv. Intell. Syst. Comput. 2019, 527-537. [CrossRef]

49. Acampa, G.; Forte, F.; De Paola, P.B.I.M. models and evaluations. In Values and Functions for Future Cities. Green Energy and Technology; Mondini, G., Oppio, A., Stanghellini, S., Bottero, M., Abastante, F., Eds.; Springer: Cham, Switzerland, 2019. [CrossRef] 